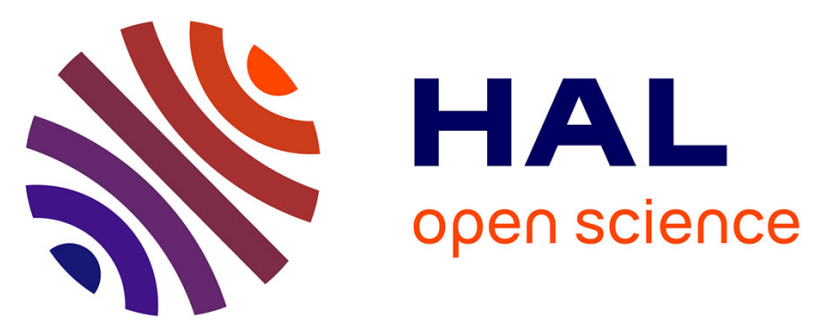

\title{
A Legal Remedy Against Rent Arrears: Landlords' Privilege on Furniture in Sixteenth- and Seventeenth-Century France
}

Nga Bellis-Phan

\section{- To cite this version:}

Nga Bellis-Phan. A Legal Remedy Against Rent Arrears: Landlords' Privilege on Furniture in Sixteenth- and Seventeenth-Century France. Laura Kolb; George Oppitz-Trotman. Early Modern Debts. 1550-1770, Palgrave Macmillan, pp.103-127, 2020, Palgrave Studies in Literature, Culture and Economics, 9783030597689. 10.1007/978-3-030-59769-6_5 . halshs-03092734

\section{HAL Id: halshs-03092734 \\ https://shs.hal.science/halshs-03092734}

Submitted on 2 Dec 2021

HAL is a multi-disciplinary open access archive for the deposit and dissemination of scientific research documents, whether they are published or not. The documents may come from teaching and research institutions in France or abroad, or from public or private research centers.
L'archive ouverte pluridisciplinaire HAL, est destinée au dépôt et à la diffusion de documents scientifiques de niveau recherche, publiés ou non, émanant des établissements d'enseignement et de recherche français ou étrangers, des laboratoires publics ou privés. 
This is the author's version of the accepted manuscript, self-archived in the institutional repository HAL-SHS after an embargo period of 12 months with the permission of Springer/Palgrave Macmillan. For reference:

BELLIS-PHAN Nga, « A legal remedy against rent arrears: Landlords' privilege on furniture in sixteenth- and seventeenth-century France », in Laura Kolb and George Oppitz-Trotman (ed.), Early Modern Debts, 1550-1700, Cham, Palgrave Macmillan, 2020 (coll. Palgrave Studies in Literature, Culture \& Economics), chap.5, p.103-127. DOI : $\underline{10.1007}$; HAL : $\underline{\text { halshs-03092734 }}$

Ce document est la version d'auteur de l'article, déposée dans HAL-SHS après une période d'embargo de 12 mois avec la permission de Springer/Palgrave Macmillan. Pour citer :

BELLIS-PHAN Nga, "A legal remedy against rent arrears: Landlords' privilege on furniture in sixteenth- and seventeenth-century France », in : Laura Kolb et George Oppitz-Trotman (éd.), Early Modern Debts, 1550-1700, Cham, Palgrave Macmillan, 2020 (coll. Palgrave Studies in Literature, Culture \& Economics), chap. 5, p. 103-127. DOI : 10.1007; HAL : halshs-03092734

*The page numbers indicated in square brackets refer to the published version of the article.

*Les numéros de pages indiqués entre crochets correspondent à la version publiée de l'article.

\title{
CHAPTER 5
}

\section{A legal remedy against rent arrears: Landlords' privilege on furniture in sixteenth- and seventeenth-century France}

\author{
Nga Bellis-Phan
}

\begin{abstract}
The frequent default in rents payments was a real challenge in the rise of urban housing in Early Modern France. Unpaid landlords were protected by customary laws with a creditor's privilege which allowed them to pursue all movable furniture brought in by the tenants, including that which had been fraudulently removed to avoid seizure. This privilege was not necessary when tenants were eager to pay their debst but became useful to minimize economic loss when they disappeared without paying. Although the privilege was confirmed in legal litterature and case law, it faced challenges arising from the royal authority's struggles to organize an efficient procedure of execution on the disputed furniture and a clear hierarchy of privileged creditors.
\end{abstract}

\author{
N. Bellis-Phan \\ University Paris 2 Panthéon-Assas, Paris, France
}




\section{$[$ p. 103*}

*The page numbers indicated in square brackets refer to the published version of the article.

*Les numéros de pages indiqués entre crochets correspondent à la version publiée de l'article.

\section{$5.1 \quad$ INTRODUCTION}

Relations between landlords and tenants in Early Modern France have inspired social and art historians, but have received less attention in legal history. This article offers a new angle for the study of early modern letting and subletting, mostly in the context of urban housing. ${ }^{1}$ It sheds light on a remarkable privilege given to landlords by written customary law, and its application during the sixteenth and seventeenth centuries. According to this rule, if tenants failed to pay their rent, landlords could legally pursue and seize all movable furniture, even the items fraudulently [p. 104] transported by the tenant to another location to avoid seizure. ${ }^{2}$ This privilege derived from the tenants' contractual obligations to pay rent and to equip the rental property with sufficient furniture. The furniture served indeed as a security for debt owed to the landlords, protecting them against potential default in payment. In fact, rent arrears were a type of high-rank privileged debt in customary law and could be executed via a dedicated procedure called gagerie or saisie-gagerie. Consequently, if the movable property of the tenant had to serve multiple creditors for execution, landlords usually received priority over competing creditors on the sale price of furniture. This privilege was particularly useful in an urban context, where relations between landlords and tenants were relatively distant compared to the steadier ties that linked landowners to farmers in rural settings.

The privilege on furniture, which was strongly protective of landlords, has firm historical roots. Originating from Roman law and consolidated in French customary

\footnotetext{
${ }^{1}$ This research work benefited from the funding and assistance of the Doctoral School o8, University Paris 2 Panthéon-Assas and the Max Planck Institute for European History (Frankfurt, Germany). The author would like to thank Pr. Sophie Démare-Lafont (University Paris 2) and Dr. Luisa Brunori (CNRSUniversity of Lille) for their helpful insight and comments on the article.

${ }^{2}$ Custom of Paris (1580), VIII, art. 171 in Nouveau coutumier général ou Corps des coutumes générales et particulières de France..., ed. Bourdot de Richebourg, 4 vols (Paris: Théodore Le Gras, 1724), III, p. 43.
} 
law, it was incorporated in the Napoleonic codifications in the nineteenth century3 and still remains effective in the latest version of the French Civil Code. 4 The main sources for exploring its scope in Early Modern France are the corpus of regional customary law and its analysis by legal treatises, along with concrete examples of early modern lease contracts established by sixteenth- and seventeenth-century Parisian public notaries. This work is the continuation of the brief study on landlords' privilege by Olivier-Martin, in his authoritative work on Parisian customary law, 5 which focused on the late medieval period. The article examines (1) the necessity of this privilege in a period of prosperity in urban housing, (2) its exceptional character in light of the general principles regarding movable securities for debt, and finally (3) the reality surrounding its effective execution.

[p. 105]

\subsection{Dealing With UnPaid Rent: A Public ORder PREOcCupation}

\subsubsection{The Rise of Urban Housing and Landlords' Difficulties} in Rent Management

Most authoritative studies on urban housing in Early Modern France deal with Paris, because of its importance and the accessibility of primary sources. ${ }^{6}$ In the middle of

\footnotetext{
3 Civil Code (1804), art. 2102 for the privilege; Code of Civil Procedure (1806), art. 819 to 825 for the procedure of saisie-gagerie.

${ }_{4}^{4}$ Civil Code (2019), art. 2332, $1^{\circ}$.

5 François Olivier-Martin, Histoire de la coutume de la prévôté et vicomté de Paris, 2 vols (Paris: Cujas, 1972), II:120-129, 579-584, 612-625.

${ }^{6}$ On Paris: Daniel Roche, Le peuple de Paris. Essai sur la culture populaire au XVIIIe siècle (Paris: Aubier-Montaigne, 1981); Annik Pardailhé-Galabrun, La naissance de l'intime. 3000 foyers parisiens XVII ${ }^{-}-X V I I I^{e}$ siècles (Paris: PUF, 1988), particularly 199-204; Anne Béroujon, Peuple et pauvres des villes dans la France moderne. De la Renaissance à la Révolution (Paris: A. Colin, 2014); Pierre Couperie and Madeleine Jürgens, 'Le logement à Paris au XVIe et XVIIe siècles', Annales. Écconomies, Sociétés, Civilisations 17, no. 3 (1962): 488-500; Pierre Couperie and Emmanuel Le Roy Ladurie, 'Le mouvement des loyers parisiens de la fin du Moyen Âge au XviII siècle', Annales. Écconomies, Sociétés, Civilisations 25, no. 4 (1970): 1002-1023; Nicolas Lyon-Caen, 'L'immobilier parisien au XVIII' siècle. Un marché locatif', Histoire urbaine 43, no. 2 (2015): 55-70; Nicolas Lyon-Caen, 'Combien vaut Paris ? La monarchie, les loyers et les boues de la capitale à l'époque moderne', Annuaire-Bulletin de la Société de l'histoire de France 552 (2014): 179-199. On other cities: Charles Liagre, Cinquante maisons de Lille. Leur situation, leurs propriétaires et leurs locataires à partir du XVIe siècle (Lille: impr. de la Croix du Nord, 1913); Sylvain Vigneron, 'Peuple des villes, peuple de locataires? Étude comparée des modalités d'habitation du peuple dans les villes de la France du Nord au XVIII' siècle', in Le peuple des villes dans
} 
the seventeenth century, the city had approximately 400,000 inhabitants and around 20,000 houses.7 Pardailhé-Galabrun demonstrated that renting was the main mode of occupation for Parisians, representing $77 \%$ of the 2113 cases her team studied for the seventeenth and eighteenth centuries. ${ }^{8}$ The variable form of rental property is a strong indication of social disparities in an urban context. Although a property could be rented in its entirety to a sole tenant, in many cases the owner would split it into different parts, with separate leases. Wealthier tenants would rent an independent house for their family, or one to two entire floors in an urban building as in the case [p. 106] of the playwright Molière. 9 The ground floor was often dedicated to a workshop or a boutique, whereas the higher floors were home to familial apartments or rooms. ${ }^{10}$ The coldest rooms under the roof were left to modest artisans who would live with their entire family in a tiny space, or to young servants or housemaids willing to share the same room. ${ }^{11} \mathrm{~A}$ lot of low-cost buildings were especially built to attract poor workers looking for one-night stay. These persons did not mind the lack of privacy of a shared place, even the most uncomfortable ones under the stairs or in the cellar. ${ }^{12}$

Wealthy owners regularly invested in one or more rental properties in Paris. Parisian notaries received regular clients like Jean Daurat, a poet, member of The Pléiade circle and professor of Ronsard. Daurat signed (as Dorat) a number of notarial acts in his role as royal poet and lecturer in Greek and Latin at the University of Paris, as the lessor of different properties, often let to university students. ${ }^{13}$ These wealthy

l'Europe du Nord-Ouest (fin du Moyen-Âge-1945), ed. Philippe Guignet, 2 vols (Lille: Publications de l'Institut de recherches historiques du Septentrion, 2003), II:417-439.

7 Pierre Chaunu, Introduction to Annik Pardailhé-Galabrun, La naissance, 11-18.

8 Pardailhé-Galabrun, La naissance, 199; table IX, 465.

9 Madeleine Jürgens and Elizabeth Maxfield-Miller, Cent ans de recherches sur Molière, sur sa famille et sur les comédiens de sa troupe (Paris: S.E.V.P.E.N., 1963; digital ed. 2009), 91 [139].

10 Couperie and Jürgens, 'Le logement', 493.

${ }^{11}$ Pardailhé-Galabrun, La naissance, 200.

${ }_{12}$ Arlette Farge, Viure dans la rue à Paris au XVIII e siècle. Choix de textes (Paris: Gallimard, 1979), 2728.

${ }^{13}$ Some examples amongst many more: For the house 'Chef Saint Jean' rue de la Grande-Bretonnerie: Paris, Archives Nationales (AN), Minutier central, MC/ET/CXXII/105, contract of 18 February 1551; MC/ET/III/221, contract of 16 January 1552-18 March 1552. For a house rue de la Harpe: MC/ET/CXXII/1237, contract of 24 November 1584-4 December 1584. For a house rue des Postes: MC/ET/XI/16, contract of 25 June 1556. For a house rue des Maçons: MC/ET/XXXIII/42, contract of 11 September 1557. 
clients did not necessarily own all the properties they handled; they could in some cases prefer to be the principal tenant and manage subletting as a form of investment. As for Jean Daurat, he bought a property on rue Saint-Germain-l'Auxerrois, ${ }^{14}$ but also rented for four years a house on rue des Sept Voies, which belonged to the Fortet College of the University of Paris. ${ }^{15}$ Landlords regularly faced difficulties managing multiple leases or even multiple properties. This is the case of another lessor, Antoine Brulon, a wealthy royal apothecary who caught the attention of social and [p. 107] theatre historians as the owner of the hôtel Brulon, where Molière and his family later rented two entire floors from his widow. ${ }^{16}$ Although he began by letting several floors of his building by himself to well-introduced tenants, he probably found the task wearisome, as the management was soon delegated to a principal tenant, who then contracted personally with subtenants. ${ }^{17}$ In fact, Molière himself was only a subtenant at the hôtel Brulon. This economic scheme of subletting was particularly frequent, as it benefited both owners, who received an early advancement on the expected rent of the subtenants, and principal tenants, who gained an important amount through the management of the rental property. ${ }^{18}$

In any case, landlords or principal tenants faced true risks of delay in payment, if not total absence of payment. The corpus of Parisian notarial leases indicates that the actual payment often happened long after the initial contractual term. ${ }^{19} \mathrm{~A}$ common practice was for early modern lessors to allow a long interval between rent collections. Unlike nowadays, where the monthly payment term constitutes the standard, it was not at all unusual to have a payment term of six months to a year. If a lessee was willing to stay for a year or more, the usual terms would be fixed twice a year, on the Nativity of St John the Baptist (mid-June) and Christmas Day, as we can see in some customary

\footnotetext{
14 Paris, AN, MC/ET/XLIX/154, contract of 29 January 1568-2 December 1580.

15 Paris, AN, MC/ET/XXXIII/46, contract of 17 July 1561.

${ }^{16}$ Madeleine Jürgens, 'Deux logis inconnus de Molière, place du Palais-Royal', XVIIe siècle 48 (1960): 16-27. Christian Warolin, 'Antoine Brulon, un riche apothicaire privilégié à Paris au XVIIe siècle, et Anne de Furnes, sa femme. Leur illustre locataire place du Palais-Royal : Molière', Revue d'histoire de la pharmacie 96, no. 361 (2009): 55-67.

${ }^{17}$ Jürgens, 'Deux logis inconnus', 23.

${ }^{18}$ Multiple examples listed in Pardailhé-Galabrun, La naissance, 199-200.

19 Paris, AN, MC/ET/XX/183, contract of 2 March 1627: more than one year after the contractual term.
} 
provisions or notarial acts. ${ }^{20}$ The lessor had to keep a vigilant eye on all changes in the lessee's situation, a difficult duty in practice. In the case of low-cost buildings destined for poor workers, the lessor and the tenants might not even know each other. Tenants seemed completely unaware of their lessor's identity or even the exact address of the rented location, with some rare exceptions. ${ }^{21}$ Poor [p. 108] tenants could easily disappear without prior notice and without paying. ${ }^{22}$ The operation could in this case be extremely risky to the lessor.

\subsubsection{The Tenants' Contractual Obligations to Pay Rent and to Provide Sufficient Furniture}

Early modern juridical treatises emphasised the tenants' obligation to equip rented lodgings with sufficient furniture, as items of furniture were considered to be securities for debt owed to the landlords by customary law. If a written contract was established, the obligation was always spelled out. A lease registered in 1665-1666 for playwright Molière (Jean-Baptiste Poquelin) and his wife Armande Béjart offers a perfect example: the tenants had 'the obligation to furnish and keep the said house and place furnished with sufficient and useful movables belonging to them in order to secure the rent'. ${ }^{23}$ This is a typical clause in use at public notarial offices. The term 'useful' (exploictables) means the landlord could easily seize and sell these movables.24 Although variations existed, the same legal keywords always appear in these contracts. In May 1565, a house near the Porte Saint Jacques was let to a student of the University

\footnotetext{
${ }_{20}$ Examples: Custom of Auxerre (Bourgogne), art. 140 ed. Jean Baptiste Née de la Rochelle, Commentaires sur la coutume du bailliage et comté d'Auxerre... (Paris: Bauche, 1749), p. 219. Paris, AN, MC/ET/III/21, contract of 16 January 1552-18 March 1552; MC/ET/CXXII/1237, contract of 24 November 1584-4 December 1584.

${ }^{21}$ Vincent Denis, 'Les Parisiens, la police et les numérotages des maisons, du XVIII ${ }^{2}$ siècle à l'Empire', French Historical Studies 38, no. 1 (2015): 83-103, see 97, note 44, quoting the declaration from a French National Archives' manuscript - Paris, AN, Y 14575, 10 January 1785.

${ }^{22}$ Farge, Vivre dans la rue, 31.

23 Paris, AN, MC/RS/395 [= MC/ET/LXXXIII/125], contract of 15 October 1665-7 January 1666. All following translations are the author's.

${ }^{24}$ David Deroussin, Histoire du droit des obligations (Paris: Economica, 2012), 256.
} 
of Paris under the condition that 'the tenant would furnish [the house] with useful movables for surety of the rent'. ${ }^{25}$

Though the more fortunate often chose to sign a notarial act, in many cases, there would be no written contract, since these were not mandatory in customary law. In fact, the chief source for contemporary historians studying urban housing in the Ancient Régime is not necessarily the body of registered leases, but sometimes death inventories. ${ }^{26}$ In the absence of a written contract, the tenant's obligation to equip the rental property was considered to be implied by the verbal agreement between the parties. In this case, the obligation lay especially heavily on the tenant. First, it [p. 109]

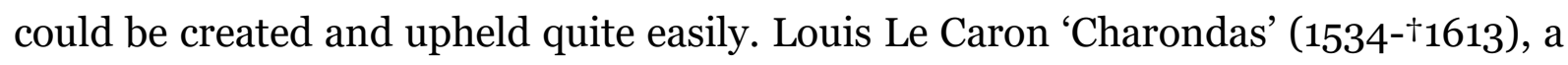
humanist jurist with great knowledge of Roman and French law, considered that even though the lessor was unaware of the furniture brought to the rental property, his rights to have it executed later must be protected. ${ }^{27}$ According to François Bourjon ( ${ }^{\dagger} 1751$ ), a later jurist working on the unification of French regional law, the obligations still existed even if the parties did not have time to discuss the amount of the rent. ${ }^{28}$ Secondly, the legal sanction was quite severe, as failure to furnish the rental property with sufficient movables could result in an immediate breach of contract. The tenant would then be asked to leave the property in eight days. ${ }^{29}$

However, the breach of contract was not automatically recognised in judicial practice. In fact, the measurement of sufficiency gave a large power of appreciation to the courts, who judged in concreto, i.e. on a case-by-case basis. The furniture should provide a liveable environment, a criteria that depended on the social conditions of the tenant. It often consisted of at least a bed, a chair and a table, some crockery and kitchenware, and basic house linens. ${ }^{30}$ Judges sometimes took into account the professional status in favour of the tenants. Bourjon pointed out a significant case law

\footnotetext{
${ }_{25}$ Paris, AN, MC/ET/XI/43, contract of 16 May 1565.

${ }^{26}$ Couperie and Jürgens, 'Le logement', 500.

${ }_{27}$ Louis Le Caron 'Charondas', Nouveau commentaire de L. Charondas... sur la coustume de la ville, prévosté et vicomté de Paris... (Paris: P. Mettayer, 1613), f. 121r.

${ }^{28}$ François Bourjon, Le droit commun de la France et la coutume de Paris réduits en principes..., 2 vols (Paris: Grangé et Cellot, 1770), II:687.

29 Decision of the Parliament of Paris, 5 October 1652: Paris, Sorbonne, HJR $4^{\circ}$ 46, 16, Arrest de reglement des loyers de maisons... (Paris: A. Perriere, 1652).
}

$3^{\circ} \mathrm{AN}, \mathrm{MC} / \mathrm{ET} / \mathrm{XXIV} / 310$, contract of 8 February 1623. 
of the Parliament of Paris ${ }^{31}$ benefiting certain performing artists, following which landlords were not entitled to require more furniture than what was necessary for their tenant's profession if the latter signed the contract in their professional status of street theatre dancer (baladin), clown (farceur) or puppeteer (joueur de marionnettes). ${ }^{32} \mathrm{~A}$ case of 1759 mentioned by Bourjon shows how this rule was still observed in the $18^{\text {th }}$ century. After a lower jurisdiction declared a lease terminated because the tenant, a puppeteer, failed to equip the property with sufficient furniture, the Parliament decided to overrule this sentence in [p. 110] favour of the tenant, arguing that he only had the obligation to bring into the rental property the instruments necessary for his profession. Although the motivations are unclear, as in most early modern court decisions, one can detect a possible reasoning by analogy with the situation of farmers or professional shopkeepers: the exercise of the profession supposed a certain valuable set of working instruments or merchandise, which was mostly sufficient to protect landlords against non-payment, rendering the housewares unnecessary.

\subsubsection{A Legal Remedy for Unpaid Landlords: \\ The Privilege of Execution on furniture}

Without a legal sanction, the tenants' obligation to pay rent and to equip their rental property would be a useless requirement. The privilege of landlords on the tenants' furniture was a concrete guarantee against potential failures in payment. The Custom of Paris, in its last written edition of 1580, would serve as an important juridical basis of this privilege. 33 According to this corpus, landlords facing non-payment of rent had the right to use a procedure of execution called gagerie or saisie-gagerie on their tenants' (art. 161) or subtenants' (art. 162) furniture. The strongest advantage of the procedure of gagerie is the fact that the seizure of furniture could be enforced without

\footnotetext{
${ }^{31}$ A Parliament during the Ancien Régime was a regional High court of justice under royal authority, not a political body of elected representatives.

${ }^{32}$ Bourjon, Le droit commun, II:46.

33 The Custom of Paris was applicable to at least one-third of the kingdom and contained very similar provisions to those pertaining to other French regional customary laws in this matter. François OlivierMartin, Histoire de la coutume de la prévôté et vicomté de Paris, I:57-68 and 75-79; François OlivierMartin, Histoire du droit français, des origines à la Révolution (Paris: CNRS Éditions, 1995).
} 
a prior authorisation by a judicial decision. 34 More importantly, even if the furniture was fraudulently removed by their tenants to avoid seizure, landlords had the 'right to follow' and 'right to be preferred', i.e. they received priority over other creditors when it came to the distribution of money from the furniture's sale (art. 171). Finally, landlords were obliged to obtain a judicial order beforehand to ensure the sale's validity, 35 and they were required, like other privileged creditors, to sell the furniture during the two months following the last oppositions from other creditors (art. 172). [p. 111]

Although the term privilege does not appear in the aforementioned texts, it is the concept used by early modern jurists to analyse landlords' rights. Deriving from the Latin privilegium, it expresses the idea of a particular right or advantage, given to a person or a group of individuals, as an exception to the general law applied to everyone. A privilege could be granted by the King, as was the privilege given to the butchers of Paris - a powerful corporation in Early Modern France - to imprison their debtors in their butcheries or at their homes in order to accelerate payment. ${ }^{6}$ Some privileges of ancient tradition had been incorporated into customary law, as in the cases of landlords, hostel masters or professional vendors; these are discussed below.

In order to justify this privilege, early modern French jurists considered the furniture as an implied pledge given to the landlords, using the Roman concept of pignus (pledge/pawn) to qualify its status. The idea that furniture would be automatically assigned to the payment of rent arrears derives directly from the Roman law of letting and hiring (locatio-conductio). In Rome, the development of insulae, urban buildings subdivided into multiple rooms or apartments to be let or sublet, rendered this privilege necessary. 37 The Praetor's Edict contained a legal remedy called

\footnotetext{
34 Claude de Ferrière, Corps et compilation de tous les Commentateurs anciens et modernes sur la Coutume de Paris, 2 vols (Paris: Denys Thierry, 1685), II, tit. VIII, 147, ${ }^{\circ} 22$.

35 de Ferrière, Corps et compilation, II, tit. VIII, 147, $\mathrm{n}^{\circ} 24$.

${ }^{36}$ Among multiple royal acts in favour of the butchers are the lettres patentes of 1522 under King François I, in Recueil général des anciennes lois françaises, ed. Isambert, Jourdan and Decrusy (Paris: Plon, 1821-1833), XII, no. 100, p. 201.

37 The latest scholarship in Roman legal history tends to place the letting and hiring (locatio-conductio) contract in its original economic and social context. For the privilege, see particularly: Bruce W. Frier, Landlords and Tenants in Imperial Rome (Princeton: Princeton UP, 1980), 105-135; Paul J. du Plessis, Letting and Hiring in Roman Legal Thought: 27 BCE-284 CE (Leiden: Brill, 2012), 150-171. See also: Roberto Fiori, La definizione della 'locatio conductio': giurisprudenza romana e traditzione
} 
the 'interdict de migrando', which prohibited tenants from taking away the furniture that served as a pledge to the landlords against non-payment. $3^{8}$ Charondas referred to the Roman law texts to conclude that any movables brought to the rental property should be seen as 'implicitly assigned to [the payment of] rent arrears'. 39 [p. 112]

\title{
5.3 AN EXCEPTIONAL PRIVILEGE CONSOLIDATED BY CUSTOMARY LAW
}

\author{
5.3.1 Historical Perspective on the Distinction between Movable \\ and Immovable Securities for Debt
}

Considering furniture as movable securities offered a flexible solution to landlords. To understand this, it is necessary to explain the place of movable securities among other means to guarantee payment. Securities for debt are legal remedies to facilitate the full payment of creditors facing insolvent debtors. In French law, the issue radically differs between movable and immovable securities for debt. This is the result of a distinction in French property law between movable and immovable property, which became fundamental in the Middle Ages and still exists in contemporary property law. $4^{\circ}$ This classification was only a minor subdivision in Roman law, where the main distinction was between res mancipi and res nec mancipi, or in German law, which instead developed a major distinction between material and immaterial properties. The French distinction was initially constructed based on the difference in monetary value between movables and immovables. Immovables were often of significant value, so their owners

romanistica (Naples: Jovene, 1999); Peter Willem De Neeve, Colonus: Private Farm-Tenancy in Roman Italy during the Republic and early Principate (Amsterdam: J. C. Gieben, 1984).

${ }^{38}$ Frier, Landlords, 105-107.

39 Le Caron 'Charondas', Nouveau commentaire, f. 121r.

$4^{40}$ For a short introduction to the history of French property law, see: Anne-Marie Patault, Introduction historique au droit des biens (Paris: PUF, 1989), 88-97. For further developments, see: Georges Goury, Origines et développement historique de la distinction des biens en meubles et immeubles, unpublished doctoral thesis (Nancy: 1897); Pierre Petot, Meubles et immeubles dans l'ancien droit français, unpublished doctoral lecture (Paris: 1938-1939); Francis Garrisson, 'Le concept de propriété [mobilière] à l'époque médiévale', in Études de droit contemporain, ed. René Rodière (Paris: Cujas, 1962), 73-89, see 73-80; Robert Villers, 'La propriété mobilière en France de l'époque des coutumes rédigées à la Révolution', in Études de droit contemporain, ed. René Rodière (Paris: Cujas, 1962), 91-99. 
had to register them at public notarial offices or at least conclude a written contract if they wish to use them as securities for debt. Such writing was often mandatory for debtors to prove their ownership and creditors to claim execution. Therefore, what really mattered was the date mentioned in the contract. Movables, on the other hand, were often objects of lesser value, which could be more easily pledged in exchange for credit. Thus, no written formality was required to prove the creditor's rights and the debtor's obligations.

If the debtor chose an immovable property as security for debt, it gave the creditor the 'right to follow' (droit de suite) and the 'right to [p. 113] be preferred' (droit de préférence). These were considered as real rights, which means they were directly attached to the debtor's goods, not to their person, as in case of personal rights. ${ }^{41}$ The right to follow was only relevant when the debtor no longer possessed the object (through sale or other forms of transfer of possession): the creditor was able to request its judicial seizure for execution against any third party. For instance, if a debtor sold or transferred the possession of a house previously given as security for debt to the creditor, the mortgage continued to exist until the full payment of the debt, regardless of any transfer of the house's ownership to a third party. In other words, the right was attached to the house itself. Additionally, the right to be preferred gave the creditor a better position among other creditors. His rank depended on the date written on the contract. He could expect to be paid first, before any other creditors, when the immovable property that had served as security was sold by the judicial authority.

If the security for debt is movable, the logic is different. Despite the simplicity of movable securities, the creditor was sometimes less protected when it came to execution. The date of the contract was often impossible to prove, so preference was given to the factual possession of the object. The best option for the creditor was to have the possession of the movable goods transferred to them in advance, like in the case of pawnbroking. As the object was already under the creditor's control in this situation, there was no need to undertake the right to follow, and the creditor was in a comfortable position to be preferred to other creditors on the sale price. However, if the creditor did not possess the movable goods, as in the case of furniture, he could find himself in a delicate situation. In fact, if the possession of movable securities was never transferred to the creditor, two general principles applied. First, the creditor had

${ }^{41}$ The term real (réel) originated from the Latin res, 'goods'. 
no right to follow the object in the hands of a third party, if the debtor had lost or transferred its possession to this person (art. 170).42 This is the famous rule 'Meubles n'ont pas de suite par hypotheque'. Second, they did not have an automatic right to be preferred, as preference had to be given to the [p. 114] first creditor who performed a valid seizure on the object (art. 178).43 In fact, customary law considered that the creditor with movable securities had to be actively involved in the execution procedure to deserve actual payment. 44

\subsubsection{The Landlord's Privilege: An Exception to the General Principles of Movable Securities for Debt}

The privilege given to landlords, especially in article 171, appeared as an exception to these general principles regarding movable securities for debt. First, landlords were given the right to follow, which was normally prohibited by article 170. Then, despite the first-come first-served basis of article 178, they also got to be 'paid first among other creditors', regardless of their involvement in and promptness of the execution, and, most of all, regardless of the first active creditor's rights. 45 Both the right to follow and the right to be preferred applied exceptionally in this case, even though furniture was ultimately just a type of movable security without a transfer of possession. The justification raised by early modern jurists lay in the special nature of these securities. Unlike pawnbroking, where the possession of the movable security was by default transferred to the creditor, in the case of landlords, the furniture that served as an implied pledge generally remained at the disposal of the tenants. The same logic applied to farmers' or artisans' professional tools, which could operate as pledges for

\footnotetext{
${ }^{42}$ Custom of Paris (1580), tit. VIII, art. 170 in Nouveau coutumier général, III:43: 'Meubles n'ont point de suite par hypotheque, quand ils sont hors de la possession du debteur.'

43 Custom of Paris (1580), tit. VIII, art. 178 in Nouveau coutumier général, III:43: 'Le creancier qui fait premier arrester \& saisir valablement, ou prendre par execution aucuns meubles appartenans à son debteur, doit estre le premier payé.'

44 Émile Jobbé-Duval, Étude historique sur la revendication des meubles en droit français (Paris: L. Larose, 1880); Francis Garrisson, 'Procédure de garantie et de revendication mobilière', Recueil de la Société d'histoire du droit et des institutions des anciens pays de droit écrit 4, no. 2 (1958-1960), 1798.

45 On the rights of the first active creditor, see: Jacques Brissaud, Le créancier 'premier saisissant' dans l'Ancien droit français (Paris: PUF, 1972).
} 
debt even as they remained in use. In these cases, even though these movable securities were not transferred to them as creditors, it was understandable that landlords received more protection than usual.

Interestingly enough, the landlord's privilege did not always benefit from such extensive effects in customary law. The strongest effects were [p. 115] only acknowledged in writing seventy years after the first written version of the Custom of Paris (1510), during a period called the Réformation phase of written customary law when the Custom of Paris was substantially edited in 1580.46 Ancient formulations were incomplete, incoherent or contained too much implicit meaning that challenged interpretation over time. In addition, legal security was not guaranteed to litigants because of contradictory rules from one region to another and the delay in rendering justice due to lack of precision in procedure. The jurists participating in the Réformation phase gave their best efforts to improve the texts, responding to a royal request and a practical need to unify legal customs in the whole kingdom. The fact that, in the order of the texts, the privilege on furniture now appeared right after the principle of 'no right to follow' (art. 170) showed the importance given to landlords' protection. The most obvious explanation for this is a juridical context inclined to favour landlords' interests. It appeared from the proceedings of the reformed edition of the Custom of Paris in 1580 that members of the three social orders were convened, but religious dignitaries and noblemen outnumbered the representatives of the tiers état. These two primary orders owned a great number of estates or properties. Letting constituted a substantial part of their active investment plans, especially for religious communities and institutions. 47 A situation where the law favours landlords is not specific to sixteenth and seventeenth-century France, as the example of Ancient Rome demonstrates. Historians of Rome have noted the 'unequal bargaining power' of lowerclass tenants and upper-class landlords, and denounced a 'law of upper-class leasehold' developed by Roman jurists who served wealthy landlords while poor tenants struggled to afford their services. $4^{8}[$ p. 116]

\footnotetext{
${ }^{46}$ Olivier-Martin, Histoire de la coutume de la prévôté et vicomté de Paris, I:104-118 on the writing process of the Custom of Paris, and pp. 42-68 on its historical and legal context.

47 Couperie and Le Roy Ladurie, 'Le mouvement', 1005.

${ }^{48}$ Reinhard Zimmermann, The law of obligations: Roman foundations of the civilian tradition (Cape Town: Juta and Co, 1990), 350; Bruce W. Frier, Landlords and Tenants in Imperial Rome, 52 and 196.
} 


\title{
5.3.3 A Privilege Considerably Strengthened by the 1580 Reformation of the Custom of Paris
}

On the principle that movable securities gave no right to follow, there was no major change in the new article 170 of the 1580 Custom of Paris. 49 However, when it comes to the exception of the landlord's privilege, there are significant modifications. Firstly, the old edition of 1510 contained only two articles dealing with such a privilege:

\begin{abstract}
Art. 163. Item, it is up to the owner (proprietaire) of a house given by them for rent to proceed by way of gagerie in the said house, for the terms due to him for the said rent, on the goods belonging to their tenant (conducteur) found in this house..$^{0}$

Art. 164. Item, when the tenant (conducteur) of a house located in the city, provostship and viscounty of Paris, (of any state or condition) fails to pay rent, for one or several terms, the pension or rent of this [house], the [principal] tenant (locateur) can proceed by way of gagerie, for the terms already due for the said rent, on the goods belonging to their tenant found in this house..$^{51}$
\end{abstract}

These articles were slightly different regarding the person entitled to seize the belongings of the insolvent tenant. They distinguished between the owner of the house (proprietaire) in article 163 and the principal tenant in charge of subletting the property (locateur) in article 164. This distinction reflects the historical context where subletting was allowed and widely practised, as previously discussed. There was still a difficulty of interpretation caused by the use of old French legal terms conducteur and locateur, which derived from Roman law, where leases (locatio-conductio or 'letting and hiring') were concluded between a locator (lessor) and a conductor [p. 117] (lessee). These terms were not adapted to describe a case of subletting. There was a debate among jurists to determine whether one could seize only the principal tenant's furniture, or also the subtenant's furniture. The difficulty of interpretation was

\footnotetext{
49 See note 38.

$5^{\circ}$ Custom of Paris (1510), XV, art. 163 in Nouveau coutumier général, III, p. 12: 'Item, il est loisible à un proprietaire d'aucune maison par luy baillée à tiltre de loyer, de faire proceder par voye de gagerie en ladite maison, pour les termes à luy deuz pour ledit louage, sur les biens du conducteur estans en icelle maison.' All following translations and emphasis are the author's.

${ }^{11}$ Custom of Paris (1510), XV, art. 164 in Nouveau coutumier général, III, p. 12: 'Item, que quand le conducteur d'aucune maison assise en la ville, prevosté \& vicomté de Paris, (de quelque estat ou condition qu'il soit) est defaillant de payer, par un ou plusieurs termes, la pension ou louage d'icelle, le locateur peut faire proceder par voye de gagerie, pour les termes escheuz à cause dudit louage, sur les biens estans en icelle maison.'
} 
inherited from a text by Ulpian, compiled by Roman Emperor Justinian in the Digest. 52 The final solution selected by customary law was to authorise seizure of the subtenants' furniture, but subtenants could retrieve it simply by paying their rent. In other words, subtenants who already executed their obligation were not responsible for the default in payment of principal tenants. This solution was observed in a decision of the Parliament of Paris in 1565. In the 1580 edition of the Custom of Paris, these articles were rewritten to reflect this 'equitable' solution, because, according to Charondas, 'it would not be reasonable to require from them more than the rent they promised to pay'.53 In order to facilitate juridical interpretation, the new edition introduced the word 'subtenants' (souslocatifs) to better integrate the case of subletting, and abandoned the words conducteur and locateur.

Art. 161. It is up to the owner (proprietaire) of a house let by them for rent, to proceed by way of gagerie in the said house, for the terms due to him for the said rent, on the goods found in this house. 54

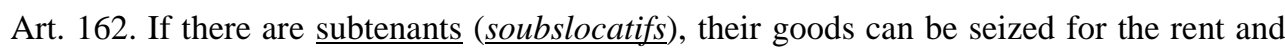
charges of the lease, although their furniture would be returned to them upon payment of their rent. 55

Secondly, the new articles 171 and 172, introduced in the 1580 edition, brought important changes to extend the privilege's scope and clarify the procedure. The proceedings of the reformed Custom of Paris, quite disappointingly, simply stated that these articles were added 'to produce their effects from now on'. ${ }^{6}[$ [p. 118]

\footnotetext{
Art. 171. However, the owners of houses situated in the cities \& suburbs, and farms with fields, can follow the executed goods of their tenants or farmers, even if they are transported, in order to be paid first among other creditors for their rent or harvest, and to be able to seize them until they are sold \& delivered by judicial authority. 57
}

\footnotetext{
${ }^{2}$ D.13.7.11.5 (Ulpian 28 ad Ed.). Cf. du Plessis, Letting, 163-166.

53 Le Caron 'Charondas', Nouveau commentaire, f. 121r.

54 Custom of Paris (1580), VIII, art. 161 in Nouveau coutumier général, III:42: 'Il est loisible à un proprietaire d'aucune maison par luy baillée à tiltre de loyer, faire proceder par voye de gagerie en ladite maison, pour les termes à luy deuz pour le louage, sur les biens estans en icelle.'

55 Custom of Paris (1580), VIII, art. 162 in Nouveau coutumier général, III:42: 'S'il y a des soubslocatifs, peuvent estre prins leurs biens pour ledit loyer \& charges du bail, \& neantmoins leur seront rendus en payant le loyer pour leur occupation.'

${ }^{56}$ Custom of Paris (1580), Proceedings, VIII in Nouveau coutumier général, III:80-81.

57 Custom of Paris (1580), VIII, art. 171 in Nouveau coutumier général, III:43: 'Toutesfois les proprietaires des maisons sizes és villes \& fauxbourgs, \& fermes des champs, peuvent suivre les biens de
} 
Art. 172. The executing [creditors] are required to sell the goods in the two months following [the last] judged or abandoned oppositions [by competing creditors]. 58

Article 171 was presented as an exception to both principles of article 170. In fact, it added the right to follow the debtor's goods 'even if they are transported' outside of the original rented location, and especially when their possession was transferred to a third party. This right was nowhere to be found in the old Custom, where both articles of the 1510 edition explicitly limited the privilege to furniture 'found in this house' (estans en icelle maison). Charles Du Moulin (1500- ${ }_{1566)}$, the most famous commentator on the old Custom of 1510, referred to other regional customs where the seizure was also limited to furniture found in the house. 59 In addition, in contrast to the silence of older articles, the right to be preferred was also explicitly confirmed in 1580, as the landlords had to be 'paid first among other creditors'. Furthermore, procedural rules were also clarified by articles 171 and 172 . The influence of royal authority is noticeable in the 1580 text, which stressed the importance of following a public procedure. The sale of goods and price sharing were to be organised by the 'judicial authority', not by landlords themselves, which tended to limit private vengeance between creditors and debtors. This particular procedure was part of the general development of a central system of justice, organised and controlled by royal [p. 119] authority. Creditors were required always to have the validity of their execution verified by royal courts and officers. Both creditors and debtors were more protected in a public procedure of execution, and a collective insolvency procedure, reuniting multiple creditors of the same debtor, was facilitated. ${ }^{6}$

A note should be added on letting of 'farms with fields' (fermes des champs), now taken into account, where the old article only mentioned 'houses in the city' (maison assise en la ville). This point alone merits extensive research, as rural leases

leurs locatifs ou fermiers executez, encores qu'ils soient transportez, pour estre premiers payez de leurs loyers ou moison, \& iceux arrester, jusques à ce qu'ils soient vendus \& delivrez par authorité de justice.'

${ }^{58}$ Custom of Paris (1580), VIII, art. 172 in Nouveau coutumier général, III:43: 'Les executans sont tenus de faire vendre les biens dedans deux mois après les oppositions jugées ou cessées.'

59 Charles Du Moulin, Les notes de maistre Charles Du Moulin sur les coutumes de France... (Paris: N. Pissot, 1715), 404 and particularly 245-247. The author refers to: Customs of Melun, art. 358; Customs of Bourbonnais, art. 117, 119; Customs of Aurillac.

${ }^{60}$ Jacques Brissaud, Le créancier 'premier saisissant' dans l'Ancien droit français (Paris: PUF, 1972); Claude Dupouy, Le droit des faillites en France avant le Code de commerce (Paris: LGDJ, 1960). 
in Early Modern France were subject to complex mechanisms due to the variety of land and ownership status, as well as contractual formats that the parties could choose from. ${ }^{61}$ According to Charondas, ${ }^{62}$ this addition was mostly introduced to determine the rank of rural land owners among privileged creditors, not necessarily to facilitate other aspects of rural farm letting and taxation, which were already extensively treated in Title I (on Fief) of the Custom of Paris. ${ }^{63}$ Rural leases differed in many ways from urban leases. Securities for debt were often taken on farming tools and labour animals, not necessarily on the furniture. Rent payment could be made with farm products and adjusted in case of poor harvests. Most importantly, relations between landlords and farmers were in general built over a long term and landlords did not suffer from the fraudulent disappearance of their tenants as in the cities.

\subsection{EFFECtiveness in EXECUTION: A STRONG PRIVILEge Challenged By UNAVOIDABLE DIFFICULTIES}

\subsubsection{The Necessity of Execution Depending on Tenants' Social Category}

The privilege itself was often the best guarantee against non-payment of rent. Delay in payment seems to have been usual in practice, even for [p. 120] solvent tenants. Notarial acts often show a lapse of time between the initial term and the date of actual payment. Even so, landlords tended to empathise with high-class tenants in particular, since it was expected that they would soon return to good fortune. In fact, the death of an important family member, civil wars or troubles, and in general the lack of liquidity could explain some difficulties in delivering the monetary sum on time. To prevent all risks, some landlords, like Antoine Brulon, were known to carefully select their tenants among people with a good reputation at court. Once they had chosen their tenants, they actively built a sustainable relationship with them, based on trust. To some,

\footnotetext{
${ }^{61}$ Fernand Braudel and Ernest Labrousse, Histoire économique et sociale de la France, 5 vols (Paris: PUF, 1977), I:540.

${ }^{62}$ Le Caron 'Charondas', Nouveau commentaire, f. 123v.

${ }^{63}$ Custom of Paris (1580), I, in Nouveau coutumier général, III:29-36.
} 
mostly royal officers, Brulon even acted generously by practising occasional money lending. 64

A private settlement between the parties to report the terms could be added to the bottom of the initial contract or in a separate act. Tenants of a certain social rank, wishing to maintain their good reputation, used to bring additional securities to the table to manifest their good faith. Most of the time, they offered a pledge that creditors could bring home, such as jewellery, linens of quality or silver crockery. In 1627 , sculptor Jean Pol-Canasse and his children owed their landlord $£ 176$ for a year of rent. ${ }^{65} \mathrm{He}$ registered a separate notarial obligation to pay rent arrears, in addition to pledging and transferring to their landlord a golden Agnus Dei, to serve as security until full payment of the rent arrears. The Pol-Canasse family obtained permission to continue their stay at this location, but this did not always happen. In 1646, English comedian Samuel Speede and his wife Anne André registered a private settlement with their landlord. ${ }^{66}$ Their $£_{385}$ debt was secured by several dresses of great value, probably for professional use, given to the landlord. The large amount of the debt could explain their promise to quit the property within four days, with full reimbursement of the amount due to their landlord.

Ultimately, execution only took place as a last resort to claim payment from debtors. It was necessary if the tenant became completely insolvent and faced multiple creditors pursuing his goods, and in the cases of poor tenants who disappeared without notice with all the furniture. [p. 121]

\subsubsection{Effectiveness of the Execution in Competition with Other Creditors}

If professional tenants became insolvent, all their creditors had to enter in competition. Landlords were not the only creditors with a privilege in customary law. Yet they enjoyed a remarkably superior position among privileged creditors67. Privileges were

\footnotetext{
64 Jürgens, 'Deux logis', 20-21.

65 Paris, AN, MC/ET/XX/183, obligation of 2 March 1627.

66 Paris, AN, MC/RE/XCVIII/2, settlement of 20 October 1646.

${ }_{67}$ Dave De ruysscher's chapter in this same volume addresses the same juridical questions on debts hierarchy in late medieval and early modern Antwerp, and demonstrates the difficulties encountered by creditors competing against each other to get paid on the debtor's goods.
} 
granted for example to hostel masters, pertaining to horses and belongings of pilgrims unable to pay after a stay in the hostel (art. 175) and to burghers of Paris regarding the belongings of their debtors from fairs (art. 173). However, in both cases, the law limited the geographical scope of their execution considerably. The hostel master could only retain the horses and belongings that were 'kept in the hostel' (hostelez):

\begin{abstract}
Art. 175. Expenses for stays in a hostel, advanced by the host to care for pilgrims or their horses, are privileged debts of higher rank to all other debts affected on the goods and horses kept in the hostel, and these can be retained by the host until payment is fulfilled; and if any other creditor wanted to seize them, the host can perform a justified opposition. 68
\end{abstract}

The privilege granted to the burghers of Paris was slightly more extensive, yet still limited to the belongings of fair debtors 'found in this city' (trouvé en icelle ville):

\begin{abstract}
Art. 173. By an ancient privilege, all burghers residing and living in Paris, for [an uninterrupted period of at least] a year and a day there, can retain by [the procedure of] arrest the goods belonging to their debtors from the fairs found in this city, [...] but not those belonging to other [categories of] debtors. 69
\end{abstract}

In fact, the only creditor who had an equivalent right to follow movables, regardless of their location, was the professional seller with a privilege on unpaid movable goods (art. 176). [p. 122]

Art. 176. The seller of movable goods without credit, expecting to be paid rapidly, can pursue his goods whenever they are transported, to be paid on the sale price. $7^{70}$

This applied when the seller allowed the buyer to take home movable merchandise, 'expecting to be paid rapidly' (esperant estre payé promptement). Such a strong privilege seems perfectly justified in this case, because without payment, a valid transfer of property to the buyer never took place. Therefore, the seller was still the lawful owner of the implicated goods and his property rights were considered to be wrongfully threatened by the malicious buyer. Lack of payment in this case could be considered equivalent to theft, for which French jurists still used the Roman law concept of furtum..$^{71}$ It is therefore understandable that the seller, in his position of creditor, should be able to follow the goods in question wherever they were transported. In comparison to the case of the seller, the landlord's rights seem less

\footnotetext{
${ }^{68}$ Custom of Paris (1580), VIII, art. 175 in Nouveau coutumier général, III:43.

${ }^{69}$ Custom of Paris (1580), VIII, art. 173 in Nouveau coutumier général, III:43.

${ }^{70}$ Custom of Paris (1580), VIII, art. 176 in Nouveau coutumier général, III:43.

${ }^{71}$ Henri Lévy-Bruhl, 'Étude historique sur la revendication du vendeur de meubles en matière de faillite', Annales de droit commercial (1938), 295-326.
} 
important, because his property rights were not under attack. Yet, he benefited from the same legal consequences, which is absolutely remarkable.

\subsubsection{Practical Difficulties due to Procedural or Administrative Uncertainties}

Royal courts were generally keen to protect the landlord's privilege. The right to follow was confirmed in a 1567 decision of the Parliament of Paris, noted by Charondas, against a malicious debtor who fraudulently transferred his furniture to a parent to avoid seizure. The right to be preferred was also regularly confirmed. Julien Brodeau

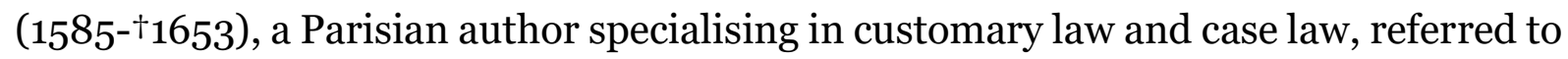
a sentence of 1581, wherein the judges decided that even if a bankruptcy procedure was opened against the tenant by their creditors, the landlord still benefited from his privilege and could not be forced to enter into competition with the other creditors as implied by the general principle of article $179 .{ }^{72}$ Brodeau also mentioned a decision of 1590, where the Parliament of Paris confirmed the right of the landlord to be paid first [p. 123] on the sale of furniture. The judges went even further by declaring that even if another creditor had been active enough to distrain the furniture themselves, the landlord should still receive payment first, because 'the privilege of his debt is so important'.73 The only challenge to the landlords' position was the absence of a clear rank classification between privileged creditors. Indeed, there was nothing in the sixteenth and seventeenth-century comparable to the written legal classification that could be later observed in the Napoleonic Civil Code. 74 Royal courts generally refused to give landlords preference if they were in competition with a creditor for funeral fees or last medical expenses, which is understandable, but landlords also lost their preference facing a constructor who repaired the property. ${ }^{75}$ Case law from this period was not consistent enough to guarantee legal security.

Another difficulty lay in the flexible character of the housing market. It allowed tenants to constantly look for a better place, and contractual terms were usually not respected. Even after a notarial contract was signed, the tenant could decide to leave

\footnotetext{
${ }^{72}$ Custom of Paris (1580), VIII, art. 179 in Nouveau coutumier général, III:43.

73 Julien Brodeau, Commentaire sur la coustume de Paris, II:569, art. 171, no. 2.

74 Code civil (1804), art. 2101-2102.

75 Le Caron 'Charondas', Nouveau commentaire, f. 124 r.
} 
with prior notice and pay compensation to the landlord. There was generally no difficulty with high-class tenants, as in the example of the potter Michel Dutrou, who decided in April 1626 to leave the house he had been renting from October 1625, initially for three years. ${ }^{76}$ As a serious tenant, he returned to the same notarial office to abandon his lease, which was reported into the original contract. He also pledged and transferred to his landlord a mould in copper, for the compensation he owed for the early departure. The situation differed fundamentally with the most vulnerable tenants, if they turned out to be unable to pay the rent. They often tried to leave secretly at night or at dusk, taking their few belongings with them. ${ }^{77}$ Although some landlords submitted a complaint to the police, their tenants did not necessarily give their real name, hometown or profession. The complaints collected by the police did not have any substantial [p. 124] effect. Despite what Milliot called the police's 'desire of omniscience', 78 if the fleeing tenants were low-wage earners with no fixed workplace, they were difficult to catch. The administrative control in place was not systematic enough to permit a comprehensive identity check. The police preferred to track down thieves or criminals who had committed more serious offences. 79

\subsection{Conclusion}

Legal rules as to tenants' contractual obligation to pay rent and to provide sufficient furniture, as well as remedies like the privilege of landlords on furniture, already existed in the Middle Ages, inspired by Roman law. In France, these tools became particularly useful in the early modern context of a rise in urban housing, where renting was the most popular mode of occupation, and letting or subletting was an interesting investment for the wealthiest. Customary rules protecting landlords against unpaid rent were considerably strengthened and clarified in the process of writing down customary law initiated in the early sixteenth century by royal authority. In substance,

\footnotetext{
76 Paris, AN, MC/ET/XLII/68, contract of 4 October 1625, renunciation of 28 April 1626.

77 Farge, Vivre dans la rue à Paris, 31.

${ }^{78}$ Vincent Milliot, Un policier des Lumières, Jean-Charles Pierre Le Noir. Suivi de Mémoires... (Seyssel: Champ Vallon, 2011), 183.

79 Vincent Milliot and Rachel Couture, 'Les inspecteurs de la Sûreté, ou "l'invention pratique" de la police judiciaire dans le Paris des Lumières', in Le nœud gordien. Police et justice: des Lumières à l'État libéral (1750-1850), ed. Marco Cicchini and Vincent Denis (Geneva: Georg Editeur, 2018), 127-162, 152.
} 
they continued to be clearly in favour of landlords, which is understandable considering their massive presence, as religious and noble orders, in the commissions destined to review the written provisions.

The privilege of landlords is of great interest to legal historians because it constitutes a strong and direct exception to a well-known principle in French property law 'Meubles n'ont pas de suite par hypotheque', which prohibits the pursuit of movable securities in the hands of a third party. The protective and powerful effects given to this privilege in the last edition of the Custom of Paris (1580) clearly show the importance attached to the protection of landlords. They were even given the same rank as professional sellers of goods, although the latter were directly attacked in their property rights, which was not the case for landlords.

In practice, execution on furniture was not always necessary, as tenants of good faith preferred to negotiate some delay in payment, in exchange [p. 125] for additional pledges or compensation. In actual cases of insolvency, royal courts and officers generally protected the superior position of landlords among privileged creditors according to customary law. Still, landlords' high rank was sometimes threatened by the absence of a predetermined legal classification of creditors. Finally, lessors who dealt with the poorest were at true risk of non-payment, as the administrative and police systems were too limited to be sufficiently active in tracking down fleeing tenants. Organizing an efficient classification of creditors according to the importance of their privilege is, however, not a problem specific to early modern French insolvency law; Dave De ruysscher's chapter on debt hierarchy in late medieval and early modern Antwerp in this volume demonstrates the same intent on the part of an urban authority to regulate such matters, confronted with doubts and hesitations regarding the best procedures to be implemented. 


\section{References}

Béroujon, Anne. Peuple et pauvres des villes dans la France moderne. De la Renaissance à la Révolution. Paris: A. Colin, 2014.

Brissaud, Jacques. Le créancier 'premier saisissant' dans l'Ancien droit français. Paris: PUF, 1972.

Carbonnier, Youri. 'Habitat et logement (du XVIe siècle à nos jours)'. In Dictionnaire historique de Paris, ed. Roselyne de Ayala. Paris: Librairie Générale Française, 2013.

Cartigny, Joël. 'Habitat et logement (au Moyen Âge)'. In Dictionnaire historique de Paris, ed. Roselyne de Ayala. Paris: Librairie Générale Française, 2013.

Couperie, Pierre, and Madeleine Jürgens. 'Le logement à Paris au XVIe et XVIIe siècles'. Annales. Économies, Sociétés, Civilisations 17, no. 3 (1962): 488-500.

Couperie, Pierre, and Emmanuel Le Roy Ladurie. 'Le mouvement des loyers parisiens de la fin du Moyen Âge au XVIIIe siècle'. Annales. Économies, Sociétés, Civilisations 25, no. 4 (1970): 1002-1023.

De Neeve, Peter Willem. Colonus: Private Farm-Tenancy in Roman Italy During the Republic and Early Principate. Amsterdam: J. C. Gieben, 1984.

Denis, Vincent. 'Les Parisiens, la police et les numérotages des maisons, du XVIIIe siècle à l'Empire'. French Historical Studies, 38, no. 1 (2015): 83-103.

Deroussin, David. Histoire du droit des obligations. Paris: Economica, 2012.

Du Plessis, Paul J. Letting and Hiring in Roman Legal Thought: 27 BCE-84 CE. Leiden: Brill, 2012.

Eleb-Vidal, Monique, and Anne Debarre-Blanchard. Architectures de la vie privée. Maisons et mentalités, XVII e-XIXe siècles. Bruxelles: Archives d'architecture moderne, 1985.

[p. 126]

Farge, Arlette. Vivre dans la rue à Paris au XVIII e siècle. Choix de texte. Paris: Gallimard, 1979.

Fiori, Roberto. La definizione della 'locatio conductio': giurisprudenza romana e traditzione romanistica. Naples: Jovene, 1999.

Frier, Bruce W. Landlords and Tenants in Imperial Rome. Princeton: Princeton University Press, 1980.

Garrisson, Francis. 'Procédure de garantie et de revendication mobilière'. Recueil de mémoires et travaux publiés par la Société d'histoire du droit et des institutions des anciens pays de droit écrit 4, no. 2 (1958-1960): 17-98.

---. 'Le concept de propriété [mobilière] à l'époque médiévale'. In Études de droit contemporain, ed. René Rodière, 73-80. Paris: Cujas, 1962.

Goury, Georges. Origines et développement historique de la distinction des biens en meubles et immeubles. Unpublished doctoral thesis. Nancy: 1897.

Jobbé-Duval, Émile. Étude historique sur la revendication des meubles en droit français. Paris: L. Larose, 1880.

Jürgens, Madeleine. 'Deux logis inconnus de Molière, place du Palais-Royal'. XVII e siècle 48 (1960): $16-27$.

Jürgens, Madeleine and Elizabeth Maxfield-Miller. Cent ans de recherches sur Molière, sur sa famille et sur les comédiens de sa troupe. Paris: S.E.V.P.E.N., 1963; digital copy ed., 2009.

Lévy-Bruhl, Henri. 'Étude historique sur la revendication du vendeur de meubles en matière de faillite'. Annales de droit commercial (1938): 295-326. 
Liagre, Charles. Cinquante maisons de Lille. Leur situation, leurs propriétaires et leurs locataires à partir du XVI e siècle. Lille: imp. de la Croix du Nord, 1913.

Lyon-Caen, Nicolas. 'Combien vaut Paris? La monarchie, les loyers et les boues de la capitale à l'époque moderne'. Annuaire-Bulletin de la Société de l'histoire de France 552 (2014): 179-199.

--_. 'L’immobilier parisien au XVIIIe siècle. Un marché locatif'. Histoire urbaine 43, no. 2 (2015): $55^{-70 .}$

Massicotte, Daniel. 'Le marché immobilier locatif à Montréal, 1731 à 1831.

Milliot, Vincent. Un policier des Lumières, Jean-Charles Pierre Le Noir. Suivi de Mémoires .... Seyssel: Champ Vallon, 2011.

Milliot, Vincent, and Rachel Couture. 'Les inspecteurs de la Sûreté, ou "l'invention pratique" de la police judiciaire dans le Paris des Lumières'. In Le noeud gordien. Police et justice: des Lumières à l'État libéral (1750-1850), ed. Marco Cicchini and Vincent Denis, 127-162. Geneva: Georg Editeur, 2018.

Olivier-Martin, François. Histoire de la coutume de la prévôté et vicomté de Paris, 2 vols. Paris: Cujas, 1972.

---. Histoire du droit français, des origines à la Révolution. Paris: CNRS Éditions, 1995.

[p. 127]

Ourliac, Paul, and Jehan de Malafosse. Histoire du droit privé, 3 vols. Paris: PUF, 1969.

Patault, Anne-Marie. Introduction historique au droit des biens. Paris: PUF, 1989.

Pardailhé-Galabrun, Annik. La naissance de l'intime. 300 foyers parisiens XVII e-XVIII e siècles. Paris: Presses universitaires de France, 1988.

Perluss, Preston. 'La reconstitution sociale des quartiers parisiens d'après les biens des gens de mainmorte'. In Etre parisien, ed. Claude Gauvard and Jean-Louis Robert, 47-62. Paris: Publications de la Sorbonne, 2004.

Petot, Pierre. Meubles et immeubles dans l'ancien droit français. Unpublished doctoral lecture. Paris, 1938-1939.

Pos, Anton Gerard. Hypotheek op roerend Goed (Bezitloos Pfandrecht). Enkele rechtshistorische en rechtsvergelijkende Beschouwingen. Ph.D. thesis. Leiden: Kl. Deventer, 1970.

---. 'Meubles n'ont pas de suite. Le sens originaire de cette règle en droit français'. Tijdschrift voor Rechtsgeschiedenis 41, nos. 1-2 (1973): 45-58.

Putman, Emmanuel. 'Sur l'origine de la règle meubles n'ont pas de suite par hypothèque'. Revue trimestrielle de Droit civil, 1994, pp. 543 sqq.

Roche, Daniel. Le peuple de Paris. Essai sur la culture populaire au XVIII e siècle. Paris: AubierMontaigne, 1981.

Tambour, Jules. Ancien droit français, vol. 2 of Des voies d'exécution sur les biens des débiteurs dans le droit romain et dans l'ancien droit français: avec un appendice sur les effets de la saisie-arrêt dans le droit actuel. Paris: A. Lacour, 1856.

Valette, Claude Denis Auguste. 'De la règle que les meubles n'ont pas de suite par hypothèque'. In Mélanges publiés par Hérold et Lyon-Caen, 2 vols, I: 247-262. Paris: A. Marescq aîné, 1880.

Vigneron, Sylvain. 'Peuple des villes, peuple de locataires? Étude comparée des modalités d'habitation du peuple dans les villes de la France du Nord au XVIIIe siècle'. In Le peuple des villes dans 
l'Europe du Nord-Ouest (fin du Moyen Âge-1945), ed. Philippe Guignet, II: 417-439. Villeneuve d'Ascq: Centre de recherche sur l'histoire de l'Europe du Nord-Ouest, 2002.

Villers, Robert. 'La propriété mobilière en France de l'époque des coutumes rédigées à la Révolution'. In Étude de droit contemporain, ed. René Rodière, 91-99. Paris: Cujas, 1962.

Warolin, Christian. 'Antoine Brulon, un riche apothicaire privilégié à Paris au XVII ${ }^{\mathrm{e}}$ siècle, et Anne de Furnes, sa femme. Leur illustre locataire place du Palais-Royal: Molière'. Revue d'histoire de la pharmacie 96, n. 361 (2009): 55-67.

Zimmermann, Reinhard. The Law of Obligations: Roman Foundations of the Civilian Tradition. Cape Town: Juta and Co, 1990. 